\title{
Metazoan parasites of common sole (Solea solea) and scaldfish (Arnoglossus laterna) (Pleuronectiformes) from Sinop coast of Black Sea
}

\author{
A. GÜVEN,T. ÖZTÜRK* \\ ${ }^{1}$ Sinop University, Faculty of Fisheries and Aquatic Sciences, 57000 Sinop, Turkey, \\ E-mail: *turkay.ozturk@gmail.com, arzu.cam86@gmail.com
}

Article info

Received October 24, 2018

Accepted February 26, 2019

\section{Summary}

The metazoan parasites were investigated of two flatfish the common sole, Solea solea $(\mathrm{n}: 140)$ and the scaldfish, Arnoglossus laterna ( $\mathrm{n}: 22$ ) in the Sinop coast of Black Sea from June 2015 to June 2017. A total of 15 metazoan parasite species belonging to Digenea (6), Cestoda (3), Acanthocephala (1), Nematoda (4) and Isopoda (1) taxonomic groups were identified. Solea solea was found to be infected by Condylocotyla pilodora, Proctoeces maculatus, Opecoelidae gen. sp., Metadena sp., Stephanostomum sp., Progrillotia sp., Capillaria gracilis, Cucullanus campanae, Solearhynchus rhytidotes and Nerocila orbignyi. Arnoglossus laterna was found to be infected by Lecithochirium musculus and Grillotia erinaceus. Scolex pleuronectis, Hysterothylacium aduncum and Dichelyne minutus were determined in both flatfish. Infection prevalence and mean intensity values were recorded for each parasite species. Infection values for each parasite species in relation to season and fish size were also determined and compared as comparatively. This study is the first one assessing the metazoan parasites both of $S$. solea and A. laterna collected from the Turkish coast of Black Sea. While Condylocotyle pilodora and Capillaria gracilis are new parasite records for S. solea, Grillotia erinecaus is new parasite record for $A$. laterna. Moreover, this paper is the first report on occurrence of Opecoelidae gen. sp., Metadena and Stephanostomum genera in S. solea.

Keywords: Common sole; Scaldfish; Metazoan parasite; Sinop; Black sea

\section{Introduction}

Pleuronectiformes, also called flatfish, are characterized by oval-shaped, flattened bodies, unique among fishes in being asymmetrical with both eyes on one side in adults. Flatfish fishery is among the most profitable demersal types of activity, since these species are economically and ecologically important part of benthic ecosystems in the world (Diaz de Astarloa, 2002; Gibson, 2005). The common sole, Solea solea (Linnaeus, 1758) and the scaldfish, Arnoglossus laterna (Walbaum, 1792) are flatfish inhabiting sandy or muddy marine bottoms of the sea floor. They feed on small bottom-dwelling invertebrates, including polychate, bivalves and crustaceans. They are to be found in the Black Sea and in the Mediterranean Sea along the west coast of Europe to Norway (Nielsen, 1973). A. laterna is caught in commercial trawlers, but it is usually discarded because of this fish species generally not being preferred for human consumption. Although it is not a commercially important species, it is important ecologically as it serves within the food chain for other predator fish. However, S. solea is a species with high commercial interest, moreover it has been shown as suitable species for aquaculture (Fanelli, 2008).

Parasites are a natural part of all ecosystems and they represent important component of the biodiversity of shallow coastal areas (Combes, 2001). Besides they play an important role for their host,

\footnotetext{
* - corresponding author
} 
as they give information about both physiology and ecology (etc. growth, condition, survival, fecundity, behaviour and population structure) of their hosts (Combes, 2001; MacKenzie and Abaunza, 2005). Parasitism is an important factor that could substantially affect on host biology, ecology and phylogeny (Marques et al., 2011). In reared fish species, it is extremely important to know which parasites are found in the target fish species. The aim of present study was to reveal the metazoan parasites of two flatfish, S. solea and A. laterna in Sinop region of the Black Sea. The diversity of parasites in relation to seasonal and size classes of the two flatfish were investigated and described for the first time in the Turkish coast of the Black Sea, in order to contribute to the knowledge on parasitofauna of demersal fish healh.

\section{Materials and Methods}

Fish samples were collected from the southern Black Sea off Sinop (N 42 $01^{\prime} 55^{\prime \prime} E 35^{\circ} 16^{\prime} 36^{\prime \prime}$ ) (Fig. 1). A total of 162 flatfish; common sole S. solea (n:140), 22 and scaldfish A. laterna (n:22) were collected between June 2015 - June 2017 with gill nets and beach seine. Fish were transferred to the laboratory and some part of them examined freshly and some part of them frozen to be examined later. At necropsy, total length and total weight of fish were mesaured. Fish were grouped in three size classes after total lengths has been measured: class $1:<14.0 \mathrm{~cm}$, class 2: 14.0$15.9 \mathrm{~cm}$, class $3:>15.9 \mathrm{~cm}$. The flatfish were dissected to check for metazoan parasites using conventional methods; assessing smears of skin, fins, gills, eyes (lens and vitreous humour), kidney, liver, stomach and intestine of fish under the dissecting microscope and then counting parasite specimens. Parasite species were identified by Gibson, 2002, Bray, 2005a;b, Miller and Cribb, 2008, Pearson, 2008 for digeneans, Lebre and Petter, 1984, Køie, 1993, Koie, 2001a, Arai and Smith, 2016 for nematodes, Campbell and Beveridge, 1994, Beveridge et al., 2004, Beveridge and Campbell, 2007 for cestodes, Belofastova, 2006 for Acanthocephala and Al-Zubaidy and Mhaisen, 2013 for Isopoda. All parasite species were examined using a stereo Olympus microscope (BX53) equipped with a digital camera (DP50). The terms prevalence (percentage of fish infected), mean intensity (mean number of parasites per infected fish), and mean abundance (mean number of parasites per examined fish) were calculated following the definitions of Bush et al. (1997). The significance of the hostparasite relationship was determined according to the abundance values; core species were those represented by $>2$ parasite species, secondary species by $0.6-2$, satellite species by $0.2-0.6$ and rare species 0.2 (Zander, 2003). The mean infracommunity was characterized as the mean number of parasite species per host individual (Zander, 2004). The differences in the mean intensities values of each parasite species for length classes of fish and seasons were tested by the Kruskal-Wallis test (Nonparametric ANOVA). All statistical analysis were done using Graph Pad Instat Software. Statistical significance level was evaluated at 0.05 .

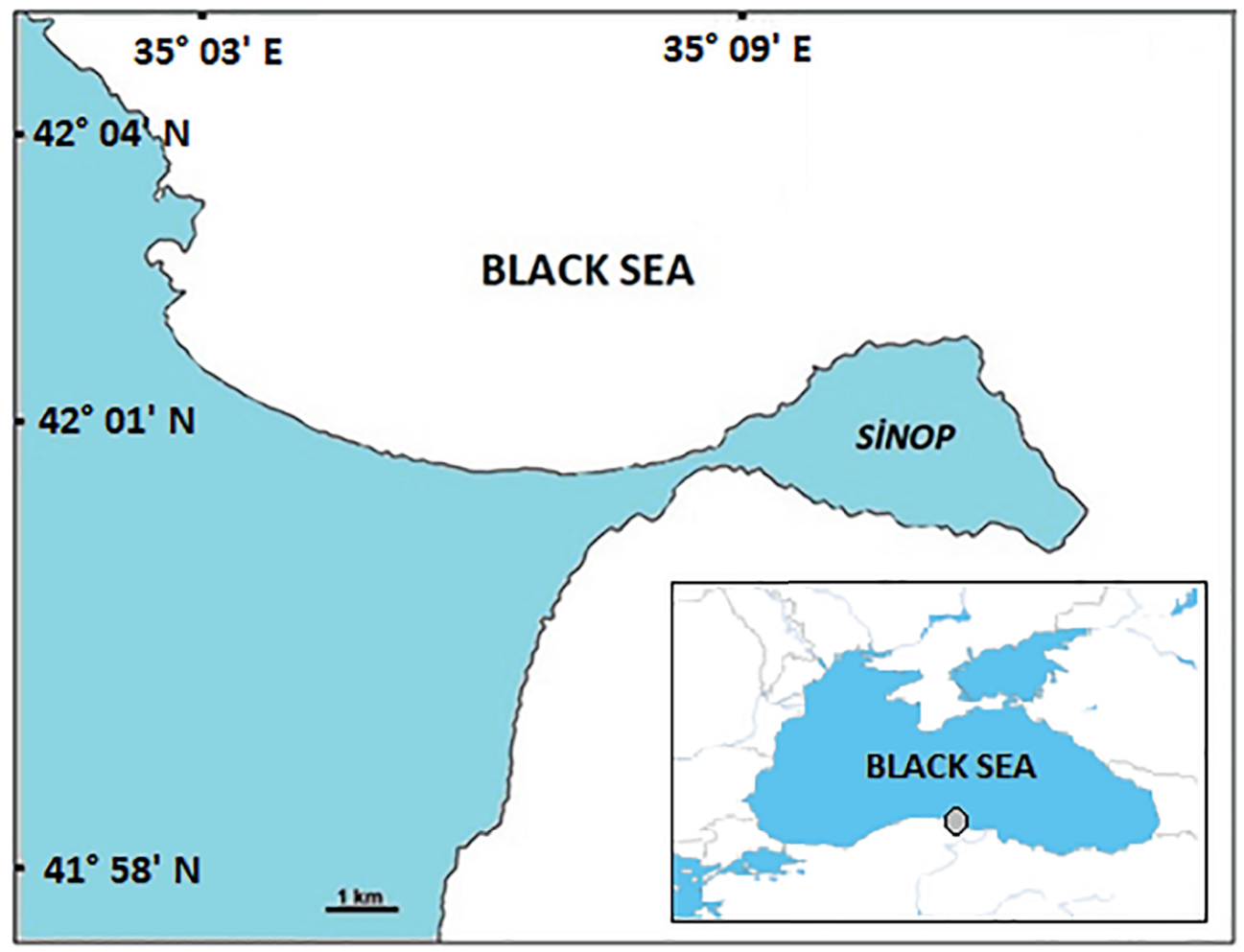

Fig. 1. The southern Black Sea off Sinop. 


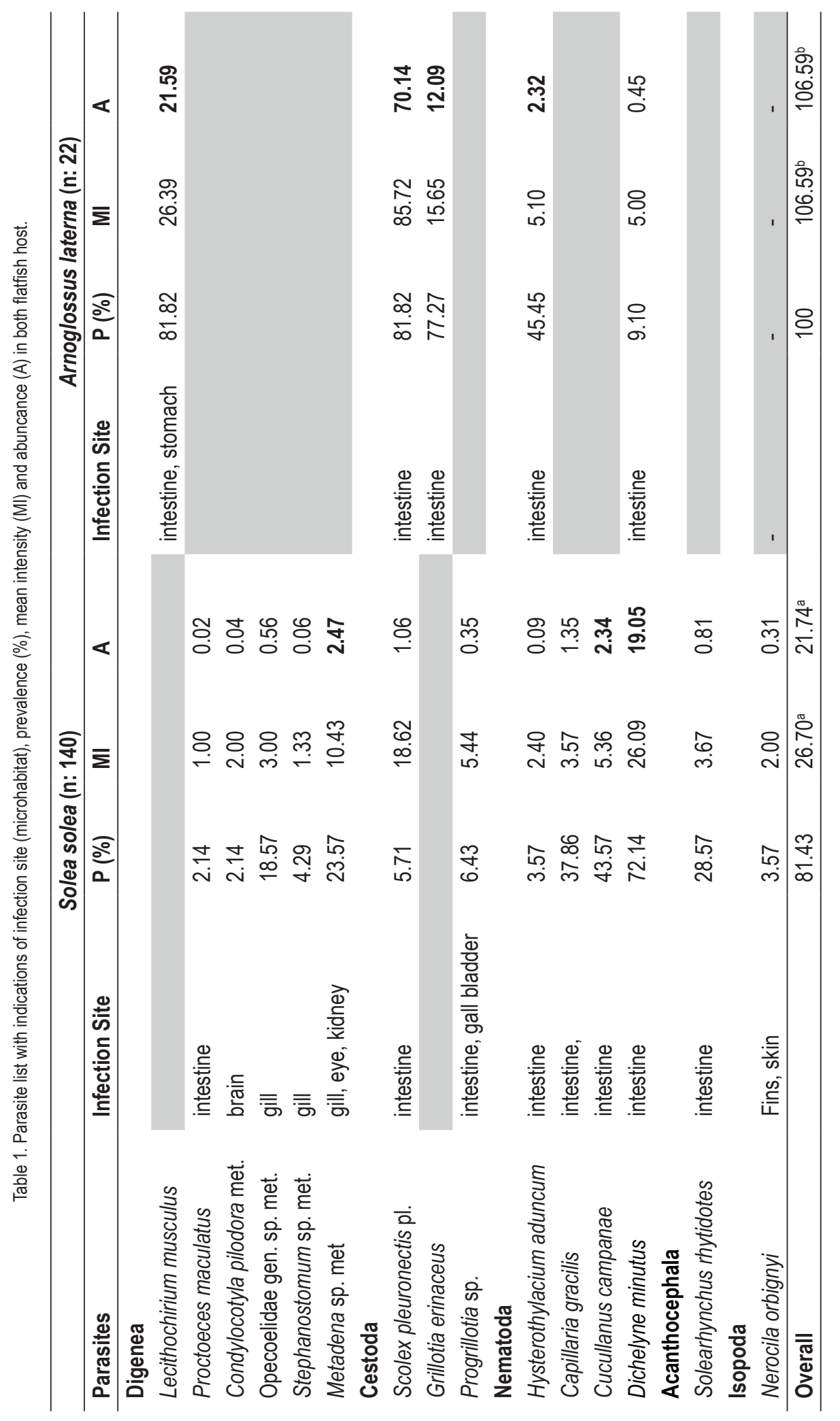




\section{Ethical Approval and/or Informed Consent}

The research related to animals use has been conformed with all the particular national regulations and institutional policies for the care and use of animals. The study protocol no. 19 of 13/07/2015 was approved by Republic of Turkey, Sinop University Experimental Animals Local Ethics Committee.

\section{Results}

In this study a total of 15 metazoan parasites were identified: five species of Digenea; Lecithochirium musculus (Hemiuridae), Proctoeces maculatus (Fellodistomidae), Condylocotyla pilodora met. (Heterophyidae), Opecoelidae gen. sp. met. (Opecoelidae), Stephanostomum sp. met. (Acanthocolpidae), Metadena sp. met. (Cryptogonimidae), three of cestodes; Scolex pleuronectis pl. (Tetraphyllidea incertae sedis), Grillotia erinaceus (Lacistorhynchidae), Progrillotia sp. (Progrillotiidae) four of Nematoda; Hysterothylacium aduncum (Raphidascarididae), Capillaria gracilis (Capillariidae), Cucullanus campanae and Dichelyne minutus (Cucullanidae), one of Acanthocephala; Solearhynchus rhytidotes (Echinorhynchidae) and one of Isopoda; Nerocila orbignyi (Cymothoidae). Table 1 summarises parasite list with indications of infection site (microhabitat), prevalence (\%), mean intensity (MI) and abuncance $(A)$ in both flatfish host. While the common sole was infected with 13 parasite species, the scaldfish was infected with only 5 parasite species. The cestode Scolex pleuronectis, the nematodes Hysterothylacium aduncum and Dichelyne minutus were determined in both host. Lecithochirium musculus and Grillotia erinaceus were found only in the scaldfish; Proctoeces maculatus, Condylocotyla pilodora, Opecoelidae gen. sp. met., Metadena sp., Stephanostomum sp., Progrillotia sp., Capillaria gracilis, Cucullanus campanae, Solearhynchus rhytidotes and Nerocila orbignyi were found only in the common sole (Table 1). Seven species, L. musculus, Metadena sp., S. pleuronectis, G. erinaceus, $H$. aduncum, $C$. campanae and $D$. minutus are designated as core species in the metazoan parasite faunas of two flatfish. In the common sole, the dominant species was $D$. minutus, while in the scaldfish, it was $S$. pleuronectis (Table 1).

Seasonal prevalence and mean intensities of metazoan parasite species in flatfish are showed in Table 2 . The species composition and the parasite species richness of the two flatfish were found to be different from each other and varied among the seasons. The overall mean intensity values of parasite species on the common sole varied significantly among the seasons $(P<0.05)$ and the highest mean intensity occurred in spring. D. minutus and $S$. rhytidotes were detected in all seasons and maximum infection prevalence was $90.2 \%$ in spring for $D$. minutus and $45.5 \%$ in autumn for $S$ rhytidotes. Metazoan parasite diversity differed between seasons. When evaluating the diversity of the parasite species depending on the seasons in the common sole, maximum value was found in spring encompassing thirteen parasite species. For the scald- fish, the parasite species richness showed no difference among seasons, except for summer. However, overall infection parameters were similar in all seasons except for summer in the scaldfish (Table 2).

The infection parameters of parasite species in selected three size classes of flatfish are given in Table 3. Opecoelidae gen. sp. met. and Stephanostomum sp. were absent in the smallest $(<14.0 \mathrm{~cm})$ and $P$. maculatus and $C$. pilodora were found only in the largest class $(>15.9 \mathrm{~cm})$ of common sole. The largest fish length class had higher overall mean intensities than the other length classes in the common sole, showing statistically significant difference $(P<0.05)$. In the scaldfish, species richness, the overall mean intensity and prevalence values were found to be independent from fish length and showed no significant differences (Table 3). A similar pattern was also seen in the mean infracommunity values between the size classes. The minimum number of parasite species was found in the smallest size class $(<14.9 \mathrm{~cm})$ in the common sole (Table 3 ).

\section{Discussion}

This study is the first on metazoan parasites of scaldfish from Turkish coast of Black Sea and $G$. erinaceus and $D$. minutus are first geographical report for scaldfish in the Black Sea. There are few studies on metazoan parasite fauna of common sole in Turkey, it is also very limited especially in Turkish coast of Black Sea. To date, only ten metazoan parasite species have been reported in the common sole in Turkish waters according to data from different authors. These are; one species of Isopoda, Nerocila orbigyni (Kayış and Ceylan, 2011) and one species of Myxozoa, Sinuolinea rebae (Özer et. al, 2015) in Black Sea, three species of Arthopoda, Caligus solea in North Eastern Mediterranean (Demirkale et. al, 2014), Caligus brevicaudatus and Caligus apodus in Eastern Mediterranean (Özak et. al, 2013), three species of Cestoda, Bothriocephalus scorpii, Grillotia sp. and Scolex pleuronectis in the Marmara Sea (Keser et. al, 2007), one species of Digenea, Hemiuridae metacercaria in the Marmara Sea (Keser et. al, 2007), one species of Nematoda, Hysterothylacium aduncum in the Marmara Sea (Keser et. al, 2007) and in Eastern Mediterranean Sea (Keskin et. al, 2015). Other studies of the metazoan parasites of common sole showed that Hysterothylacium aduncum, S. pleuronectis, Solearhynchus rhytidotes (syn: S. kostylewi) and Nerocila orbignyi were previously reported. We found 13 parasite species; 6 of these had already been mentioned in published studies, but so far, 7 species, Condylocotyla pilodora, Proctoeces maculatus, Opecoelidae gen. sp. met., Metadena sp., Stephanostomum sp., Capillaria gracilis and Progrillotia sp. haven't been reported in the common sole, and this is their first report. But, C. pilodora, P. maculatus and Stephanostomum sp. have been detected in low intensity and is being registered as rare species during this investigation. Therefore, we consider that their presence in the common sole is accidental and that they are parasites of other fish species in the study area.

In this study, Digenea was the most represented taxa with a total 


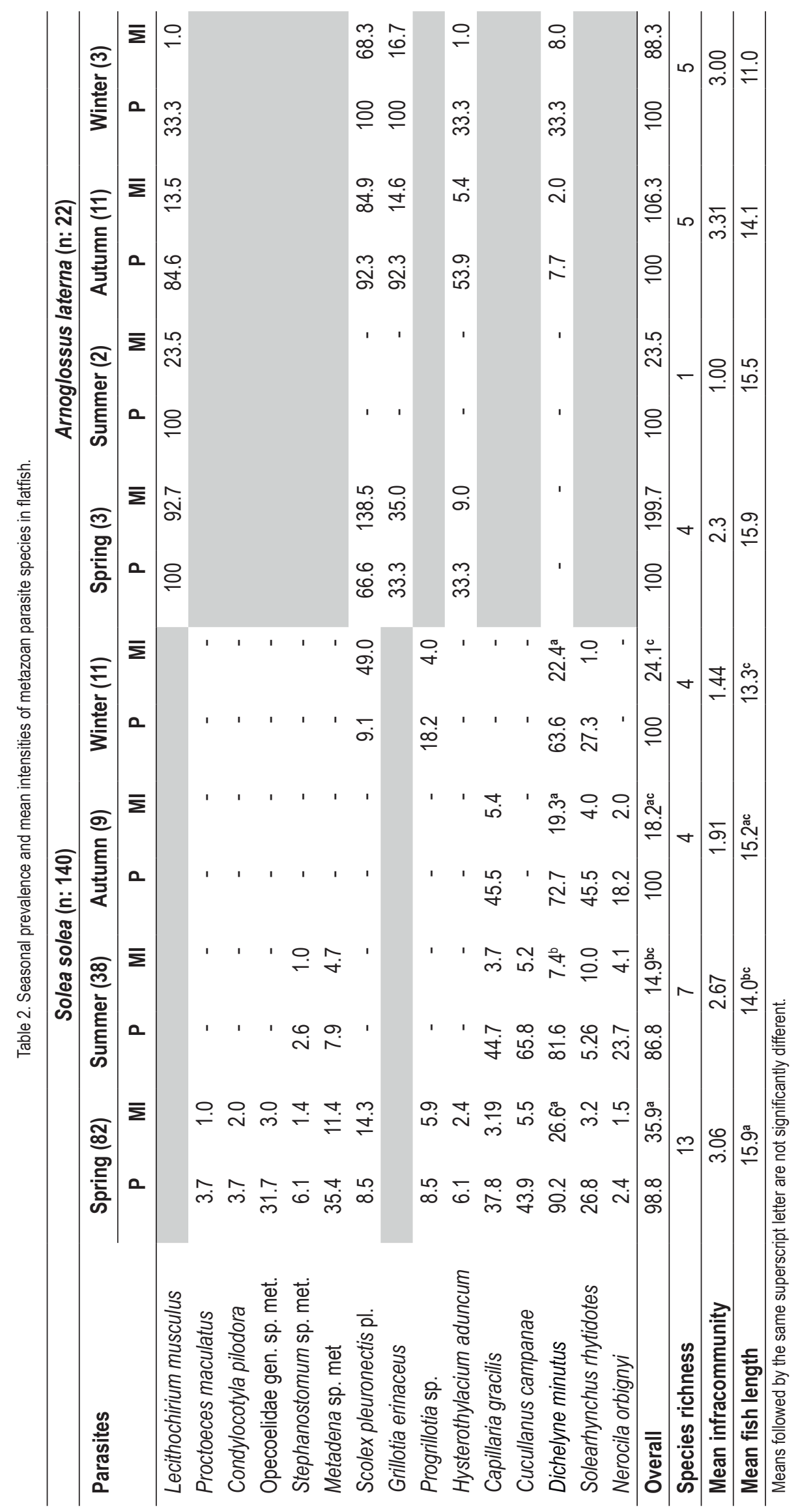


6 species, 2 adults (L. musculus and P. maculatus) and 4 metacercariae stage (C. pilodora, Opecoelidae gen. sp. met., Stephanostomum sp. and Metadena sp.). Among the Digeneans, only the $L$. musculus was detected in the scaldfish, the other 5 digenea parasites were detected in the common sole. Except $L$. musculus, other digeneans were observed in spring and summer seasons. Release of digenean cercariae from the snail host and successful transmission to the fish host is highly temperature-dependent. In this study the prevalence of digenean species in spring and summer may be explain with water temperature.

Fish size had an effect in both species diversity and mean intensity of digenean species. In general, mean intensity values were positively correlated with fish size in the common sole (Table 3). Proctoeces maculatus, C. pilodora, Stephanostomum sp. and Opecoelidae gen. sp. met. were absent in the smallest fish size class $(<14.0 \mathrm{~cm})$. The absence of these parasites can be explained by dietary differences related to fish length groups. Studies of dietary composition show that the food of the common sole consists of bottom-dwelling invertebrates, such as Polichaeta, Crustacea, Mollusca. The variety of habitats, for example site type, e. g. shallow coastal areas, continental shelf, estuarine systems and the range of fish lengths account for dietary dissimilarities (Muus and Dahlström 1991; Banaru and Harmelin-Vivien, 2009; Cabral 2000).

Four nematode species, Hystherothylacium aduncum, Capillaria gracilis, Dichelyne minutus and Cucullanus campanae were determined in two flatfish during the present investigation. The common sole was found to be infected with above mentioned four nematode species, the scaldfish was infected with $H$. aduncum and $D$. minutus. Among recorded nematodes, $D$. minutus and $C$. campanae as core species, $C$. gracilis as secondary species and $H$. aduncum as rare species were determined in the common sole. Whereas in the scaldfish, the $H$. aduncum was detected as core species, and D. minutus as satellite species (Table 1). Cucullanus campanae is specific parasite of the common sole (Koie, 2000). Similarly, $D$. minutus is a typical and common parasite of demersal fishes such as flounders and gobies (Moravec, 1994; Koie, 2001a). Dichelyne minutus uses usually the polychaete Hediste diversicolor as an obligate intermediate host, and members of gobiid and flatfish are the definitive hosts of this nematode (Koie, 2001a). H. diversicolor has been indicated as the first intermediate host of this nematode in also Black Sea and mature individuals of $D$. minutus were reported in various species of fish (Pronkina et al., 2017). In the present study, seasonal changes in the mean intensity and prevalence of $D$. minutus were determined. The highest prevalence value was recorded in spring (Table 2). Similarly in spring, Pronkina et al. (2017) reported high prevalence from the definitive hosts in the Black Sea. The results obtained in the present study are in good agreement with Pronkina et al. (2017).

Capillaria gracilis which is known mainly as a parasite of gadoid fish, uses usually oligochaetes and rarely fish as the intermediate hosts. It has been reported that gobies act as obligatory intermediate hosts (Koie 2001b). The prevalence value of $C$. gracilis was higher in summer than in other seasons and it was not detected in winter (Table 2). The mean intensity values were also positively correlated with increasing fish size (Table 3). Seasonal average length of fish in winter is lower and this clearly explains its absence in winter. Thus our results indicated that the infection prevalence had a relation with host size.

Scolex pleuronectis (pleurocercoid), Grillotia erinaceus and Progrillotia sp. were the cestod parasites determined in the present study. S. pleuronectis and G. erinaceus were the core and dominant species for the scaldfish as seen in overall infection values (Table 1). However S. pleuronectis has been previously reported in certain fish species in the same sampling region (Güneydağ et al. 2017). Similarly, G. erinaceus has been reported in Merlangius merlangus in the same sampling area (Özer et al., 2014). Two cestodes species are reported in the scaldfish first time with this study. Moreover, the prevalence and mean intensity values obtained were significantly higher for both cestode species compared with previous reported in the region. Therefore, we suggest that the scaldfish is the principal second intermediate host for both cestode.

Solearhynchus rhytidotes is a rare parasite of the common sole. It is redescribed and reported in the common sole captured from the Sea of Marmara by Kvach and Oğuz, 2010.

Nerocila orbignyi was detected from fin and skin in the common sole. The presence of $N$. orbignyi has been previously reported in the common sole from Black Sea by Kayış and Ceylan, 2011. In this study, detailed data related with infection values both $S$. rhytidotes and $\mathrm{N}$. orbignyi were presented for the first time in Turkey. Although the scaldfish had lower number of parasite species then the common sole, the highest prevalence and intensity values (100\% and 106.59) were found in scaldfish (Table 1). The results of this study showed that many parasite species prefer the common sole rather than the scaldfish. It could be due to effect of dietary preferences. The scaldfish, Arnoglossus laterna is a highly motile and selective predatory, it feeds on small fishes and invertebrates (Fanelli et al., 2009). Conversely, the common sole, Solea solea is sedentary predatory, it feeds upon worms, mollusks, and small crustaceans that most of them are infected with parasites (Cabral 2000).

Solea solea has different prey groups compared to A. laterna and this study shows that this different diet compositions may affect parasite species diversity. Although this is a factor influencing parasite load and parasite diversity, diet diversity alone cannot fully explain it. Additionally our results indicated that the number of parasite species had a relation with host size in particular S. solea. It can be due to the composition and diversity of the ingested prey varied with the size of predator fish and increased of the diet of larger specimens than smaller ones.

In conclusion, the data presented in this study contribute to the knowledge on metazoan parasites in two flathfish and add some valuable information on its occurrence on seasonal level and the relation with hosts size. 


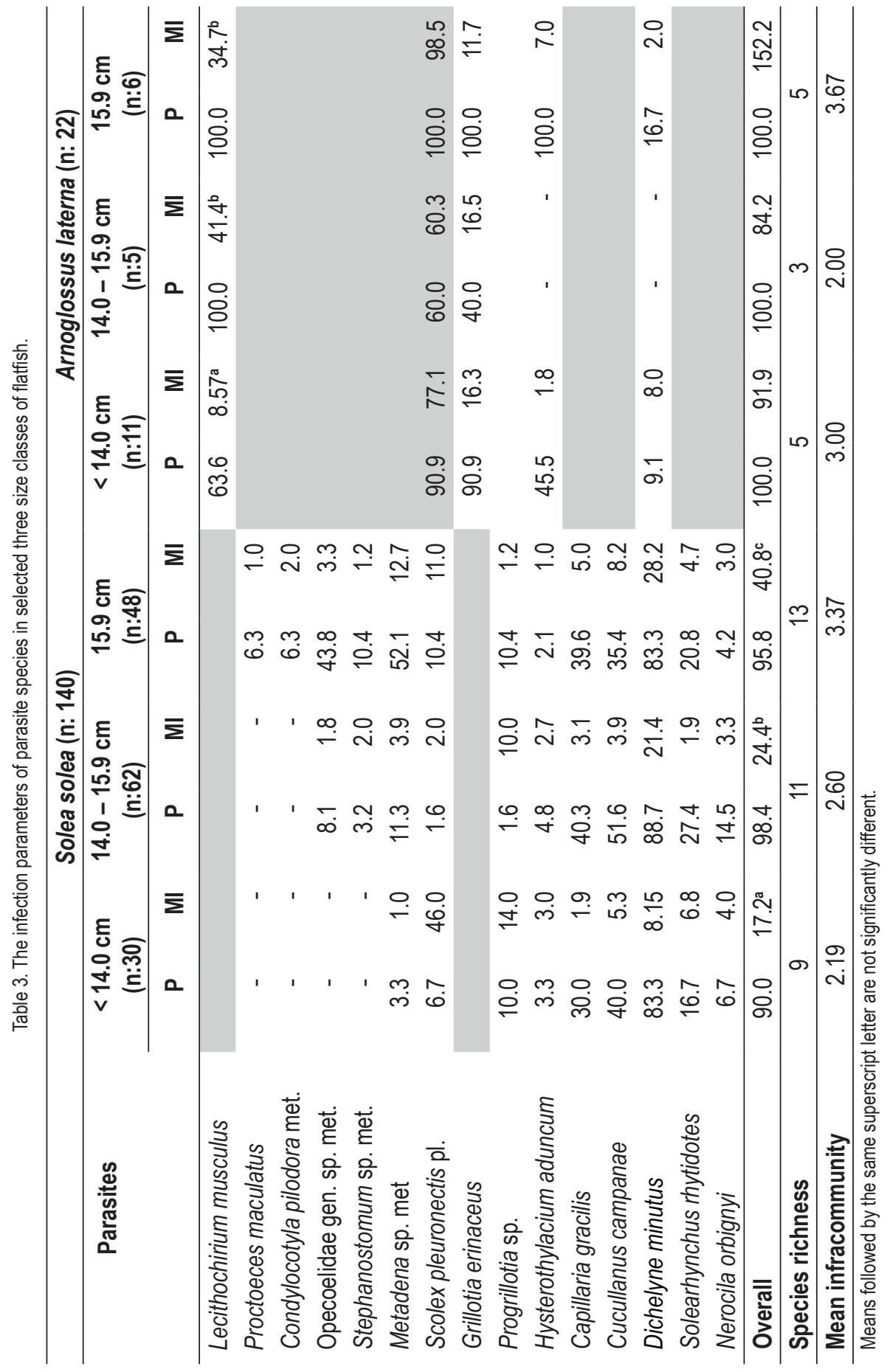




\section{Conflict of Interest}

Authors state no conflict of interest

\section{Acknowledgement}

Authors are grateful to The Scientific and Technological Research Council (TÜBITAK) of Turkey for its financial support in a part of this study with the project number of 2150224

\section{References}

Al-Zubaidy, A. B., Mhaisen, F. T. (2013): The first record of three cymothoid isopods from Red Sea fishes, Yemeni coastal waters. International Journal of Marine Science, 3(21): 166 - 172. DOI: 10.5376/ijms.2013.03.0021

ARAl, H. P., Smith, J. W. (2016): Guide to the Parasites of Fishes of Canada Part V: Nematoda. Zootaxa, 4185(1): 1 - 274. DOI: 10.11646/zootaxa.4185.1.1

Banaru, D., Harmelin-Vivien, M. (2009): Trophic links and riverine effects on food webs of pelagic fish of the Northwestern Black Sea. Mar. Freshw. Res., 60: 529 - 540. DOI: 10.1071/MF08005

Belofastova, I. P. (2006): Solearhynchus rhytidotes nov. comb. (Palaeacanthocephala: Echinorhynchidae), a parasite of soles (Soleidae). Parazitologiia, 40(1): 85 - 93

Beveridge, I., Neifar, L., Euzet, L. (2004): Review of the genus Progrillotia Dollfus, 1946 (Cestoda: Trypanorhyncha), with a redescription of Progrillotia pastinacae Dollfus, 1946 and description of Progrillotia dasyatidis sp. n. Folia parasitol., 51(1): 33. DOI: 10.14411/fp.2004.005

Beveridge, l., Campbell, R. A. (2007): Revision of the Grillotia erinaceus (van Beneden, 1858) species complex (Cestoda: Trypanorhyncha), with the description of G. brayi n. sp.Syst. Parasitol., 68(1): 1 - 31. DOI: 10.1007/s11230-006-9082-2

BraY, R.A. (2005a): Family Acanthocolpidae Lühe (1906): In: Jones, A., Bray, R.A., Gibson, D.I. (Eds) Keys to the Trematoda. Volume 2. London, UK: CABI Publishing and The Natural History Museum, pp. $603-619$

Bray, R.A. (2005b): Family Fellodistomidae Nicoll, 1909. In: BraY, R.A., GiBson, D.I., Jones, A. (Eds) Keys to the Trematoda. Volume 3. London, UK: CABI Publishing and The Natural History Museum, pp. $261-293$

Bush, A.O., LAfFerty, K.D., Lotz, J.M., Shostak, A.W. (1997): Parasitology meets ecologyon its own terms: Margolis et al. revisited. J. Parasitol., 83: 575 - 583. DOI: 10.2307/3284227

CABRAL, H.N., (2000): Comparative feeding ecology of sympatric Solea solea and $S$. senegalensis, within the nursery areas of the Tagus estuary, Portugal. J. Fish Biol., 57: 1550 - 1562. DOI: 10.1006/jfbi.2000.1408

Campbell, R.A, Beveridge, I. (1994): Order Trypanorhyncha Diesing, 1863. In: KhallL L.F., Jones A., Bray R.A. (Eds) Keys to the cestode parasites of vertebrates. CAB International, Walling- ford, pp $51-148$

COMBES, C. (2001): Parasitism: The Ecology and Evolution of Intimate Interactions. University of Chicago Press, Chicago.

Demirkale, I., Özak, A. A., Yanar, A., Boxshall, G. A. (2014): Caligus solea n. sp.(Copepoda: Caligidae) parasitic on the common sole Solea solea (Linnaeus) from the north-eastern Mediterranean off the Turkish coast. Syst. Parasitol., 89(1): 23 - 32. DOI: 10.1007/ s11230-014-9505-4

Diaz de AstarloA, J. M. (2002): A review of the flatfish fisheries of the south Atlantic Ocean. Rev Biol Mar Oceanogr, 37(2): 113 - 125 Fanelul, E. (2008): Trophic Relationships in Demersal Communities of Western Mediterraneo Occidentale: Case Studies From Coastal and Deep-sea Ecosystems. Ph D Thesis, Italy: Universita' degli Studi di Viterbo "La Tuscia", ICM-CSIC, 327 p.

Fanelli, E., Badalamenti, F., D'anna, G., Pipitone, C. (2009): Diet and Trophic Level of Scaldfish Arnoglossus Laterna in The Southern Tyrrhenian Sea (Western Mediterranean): Contrasting Trawled Versus Untrawled Areas. J. Mar. Biolog. Assoc. U.K., 89(4): 817 828. DOI: 10.1017/S0025315409000137

GIBSON, D.I. (2002): Family Hemiuridae Looss, 1899. In: GIBSoN, D.I., Jones, A., Bray, R.A. (Eds) Keys to the Trematoda. Volume 1. London, UK: CABI Publishing and The Natural History Museum, pp. $305-340$

GiBson, R.N. (2005): Flatfishes. Biology and Exploitation. Oxford, UK, Blacwell Publishing, 391 pp.

GüneydaĞ, S., Özkan, H., Özer, A. (2017): Scolex pleuronectis (Cestoda) Infections in Several Bony Fish Species Collected from Sinop Coasts of the Black Sea. Sinop Uni J Nat Sci., 2(1): 150 158

KAYIŞ, Ş., CEYLAN, Y. (2011): First report of Nerocila orbigyni (Crustacea, Isopoda, Cymothoidae) on Solea solea (Teleostei, Soleidae) from Turkish Sea. Turk J Fish Aquat Sci, 11: 167 - 169. DOI: 10.4194/trjfas.2011.0123

Keser, R. Bray, R.A., Oguz, M.C., Çelen, S., Erdoğan, S., DoĞutURK, S., AKLanoĞLu, G., Marti, B. (2007): Helminth parasites of digestive tract of some teleost fish caught in the Dardanelles at Çanakkale, Turkey. Helminthologia, 44 (4): 217 - 221. DOI: 10.2478/s11687-007-0035-3

Keskin, E., Koyuncu, C. E., Genc, E. (2015): Molecular identification of Hysterothylacium aduncum specimens isolated from commercially important fish species of Eastern Mediterranean Sea using mtDNA cox1 and ITS rDNA gene sequences. Parasitol. Int., 64(2): 222 - 228. DOI: 10.1016/j.parint.2014.12.008

Lèbre, C., Petter, A. J. (1984): Cucullanus campanae n. sp. (Cucullanidae, Nematoda), parasite de la Sole Solea vulgaris vulgaris (Pleuronectiformes). Bull. Mus. natn. Hist. nat., 4(6): 999 - 1005. Kø|E, M. (1993): Aspects of the life cycle and morphology of Hysterothylacium aduncum (Rudolphi, 1802) (Nematoda,Ascaridoidea, Anisakidae). Can. J. Zool., 71: 1289 - 1296

KøাE, M. (2001a): The life cycle of Dichelyne (Cucullanellus) minutus (Nematoda: Cucullanidae). Folia Parasitol., (48); 304 - 310. DOI: $10.14411 / \mathrm{fp} .2001 .048$ 
Køıє, M. (2001b): The life-cycle of Capillaria gracilis (Capillaridae), a nematode parasite of gadoid fish. Sarsia, 86: 383 - 387. DOI: 10.1080/00364827.2001.10425525

KvaCH, Y., OĞuz, M. C. (2010): Solearhynchus kostylewi (Meyer, 1932) comb. nov.(Acanthocephala: Echinorhynchidae), a rare parasite of Solea solea (Pisces: Soleidae) in the Gemlik Bay, Sea of Marmara. Parasite, 17(1): 47 - 51. DOI: 10.1051/parasite/2010171047

MacKenzie, K., Abaunza, P. (2005): Parasites as biological tags. In Stock Identification Methods. Applications in Fisheries Science (eds S.X. Cadrin, K.D. Friedland \& J.R. Waldman). San Diego, USA., Elsevier Academic Press, pp. 211 - 226

Marques, J.F., Santos, M.J., Teixeira, C.M., Batista, M.I., Cabral, H.N. (2011). Host-parasite relationships in flatfish (Pleuronectiformes) - the relative importance of host biology, ecology and phylogeny. Parasitol., 138(1): 107 - 121. DOI: $10.1017 /$ S0031182010001009

MILleR, T.I., CRIBB, T.H. (2008): Family Cryptogonimidae Ward, 1917. In: Bray, R.A., GiBSON, D.I., Jones, A. (Eds) Keys to the Trematoda. Volume 3. London, UK: CABI Publishing and The Natural History Museum, pp. 51 - 112

Moravec, F. (1994): Parasitic Nematodes of Freshwater Fishes of Europe. Praha and Dordrecht, Boston, London, Academia and Kluwer Acad. Publishers, pp. 473

MuUs, B. J., Dahlström, P. (1991): Marine Fishes of the Baltic and North Seas, and Atlantics - Biology, Fishery and Economy. BLVKey-Book, 6 ed. Munich: Verllagsgesselschaft mbH.

Nielsen, J. (1973): Bothidae. In: Hureau, J.C., Monod, T. (Eds) Check List of Fishes of The North-Eastern Atlantic and of The Mediterranean. Paris, UNESCO, pp. 620 - 622
Özak, A. A., Demirkale, I., Boxshall, G. A., Etyemez, M. (2013): Parasitic copepods of the common sole, Solea solea (L.), from the Eastern Mediterranean coast of Turkey. Syst. Parasitol., 86(2): 173 - 185. DOI: 10.1007/s11230-013-9441-8

ÖZer, A., ÖZtÜrk, T., Kornyushin, V.V., KornyYchuK, Y., YURAKhno, V. (2014): Grillotia erinaceus (van Beneden, 1858) (Cestoda:Trypanorhyncha) from whiting in the Black Sea, with observations on seasonality and host-parasite interrelationship. Acta Parasitol., 59(3): 420 - 425. DOI: 10.2478/s11686-014-0261-z

Özer, A., Özkan, H., GüneYdaĞ, S., Yurokhno, V. (2015): First Report of Several Myxosporean (Myxozoa) and Monogenean Parasites from Fish Species off Sinop Coasts of the Black Sea. Turk J Fish Aquat Sci, 15(3): 737 - 744. DOI: 10.4194/1303-2712-v15_3_18 PeARSON, J. (2008): Family Heterophyidae Leiper, 1909. In: BraY, R.A., Gibson, D.I., Jones, A. (Eds) Keys to the Trematoda. Volume 3. London, UK: CABI Publishing and The Natural History Museum, pp. $113-141$

Pronkina, N.K, Dmitrieva, E.V., Polyakova, T.A., Popyuk, M.P. (2017): The Lifecycle of Dichelyne minutus (Rudolphi, 1819) (Nematoda: Cucullanidae) in the Estuarine Biocenosis of the Black Sea. Russ J Mar Biol, 43(2): 148 - 155. DOI: 10.1134/S1063074017020079

ZANDER, C.D. (2003): Four-year monitoring of parasite communities in gobiid fishes of the south-western Baltic: I. Guild and component community. Parasitol. Res., 90: 502 - 511. DOI: 10.1007/ s00436-003-0887-5

ZANDER C.D. (2004): Four-year monitoring of parasite communities in gobiid fishes of the south-western Baltic. II. Infracommunity. Parasitol. Res., 93 : 17 - 29. DOI: 10.1007/s00436-004-1087-7 